\title{
BMJ Open Real-world persistence and adherence with oral bisphosphonates for osteoporosis: a systematic review
}

\author{
F Fatoye, P Smith, T Gebrye, G Yeowell
}

To cite: Fatoye F, Smith $P$, Gebrye T, et al. Real-world persistence and adherence with oral bisphosphonates for osteoporosis: a systematic review. BMJ Open 2019;9:e027049. doi:10.1136/ bmjopen-2018-027049

- Prepublication history and additional material for this paper are available online. To view these files, please visit the journal online (http://dx.doi org/10.1136/bmjopen-2018027049).

Received 4 October 2018 Revised 14 January 2019 Accepted 13 February 2019

Check for updates

(C) Author(s) (or their employer(s)) 2019. Re-use permitted under CC BY-NC. No commercial re-use. See rights and permissions. Published by BMJ.

Department of Health Professions, Manchester Metropolitan University,

Manchester, UK

Correspondence to

Professor F Fatoye;

f.fatoye@mmu.ac.uk

\begin{abstract}
Objectives This study examined patient adherence and persistence to oral bisphosphonates for the treatment of osteoporosis in real-world settings.

Methods A systematic review was completed according to the Preferred Reporting Items for Systematic Reviews and Meta-Analyses. Medical Literature Analysis and Retrieval System Online (MEDLINE), Cumulative Index to Nursing and Allied Health Literature (CINAHL), Allied and Complementary Medicine Database (AMED), Database of Abstracts of Reviews of Effects (DARE), Health Technology Assessment (HTA) and National Health Service Economic Evaluation Database NHS EED) databases were searched for studies published in English language up to April 2018. Prospective and retrospective observational studies that used prescription claim databases or hospital medical records to examine patient adherence and persistence to oral bisphosphonate treatment among adults with osteoporosis were included. The Newcastle-0ttawa quality assessment scale (NOS) was used to assess the quality of included studies.
\end{abstract}

Results The search yielded 540 published studies, of which 89 were deemed relevant and were included in this review. The mean age of patients included within the studies ranged between 53 to 80.8 years, and the follow-up varied from 3 months to 14 years. The mean persistence of oral bisphosphonates for 6 months, 1 year and 2 years ranged from $34.8 \%$ to $71.3 \%, 17.7 \%$ to $74.8 \%$ and $12.9 \%$ to $72.0 \%$, respectively. The mean medication possession ratio ranged from $28.2 \%$ to $84.5 \%$, $23 \%$ to $50 \%, 27.2 \%$ to $46 \%$ over 1 year, 2 years and 3 years, respectively. All studies included scored between 6 to 8 out of 9 on the NOS. The determinants of adherence and persistence to oral bisphosphonates included geographic residence, marital status, tobacco use, educational status, income, hospitalisation, medication type and dosing frequency.

Conclusions While a number of studies reported high levels of persistence and adherence, the findings of this review suggest that patient persistence and adherence with oral bisphosphonates medications was poor and reduced notably over time. Overall, adherence was suboptimal. To maximise adherence and persistence to oral bisphosphonates, it is important to consider possible determinants, including characteristics of the patients.

\section{INTRODUCTION}

Osteoporosis is a chronic global health condition, characterised by low bone density

\section{Strength and limitation of this study}

This review only included prospective and retrospective observational studies that derived objective prescription claim data from outside clinical trial settings, to better reflect real-world adherence and persistence to oral bisphosphonates for the treatment of osteoporosis.

- This review was able to derive persistence and adherence data from 89 observational studies performed within 15 different countries,

- The calculation of persistence and adherence across the included studies were heterogeneous. As a result, it was not possible to directly compare these studies via meta-analysis.

- The review did not collect self-reported patient data. This data may have given further insight as to the determinants of persistence and adherence among patients with osteoporosis.

and bone structure deterioration. ${ }^{1}$ About a third of men and more than half of all women experience osteoporosis during their lives. ${ }^{2}$ Moreover, evidence suggests that fracture-related mortality rate is higher in men than women. ${ }^{3}$ The first sign of osteoporosis is often a fracture of the wrist, hip and spine. Osteoporotic fractures can lead to long-term problems such as chronic pain, long-term disability and even death. ${ }^{4}$ The long-term problems of osteoporosis may also lead to a substantial economic burden on individuals, health systems and society. Osteoporosis is a common disease in the USA, and more than 1.5 million osteoporosis-related fractures occur each year. ${ }^{5}$ For example, the findings of a study of osteoporosis-related fractures in the USA indicated that patients with a diagnosis of osteoporosis and concurrent fracture $(\$ 15,942)$ had more than two times the annual healthcare expenditure, compared with patients with osteoporosis without a fracture $(\$ 6,476) .^{5}$ The total cost estimates for the treatment of osteoporosis and subsequent care in the USA was around $\$ 17$ billion in 2003 and this is expected to increase by 
$50 \%$ in $2025 .^{67}$ The majority of this cost is spent on acute surgical and medical management, and subsequent rehabilitation. ${ }^{6}$

Bisphosphonate medications for osteoporosis have been shown to increase bone strength and reduce fracture risk and can be administered orally or intravenously across a wide range of doses and dosing intervals. ${ }^{89}$ Bisphosphonate treatments such as etidronate, alendronate, ibandronate, risedronate and zoledronic acid are able to prevent vertebral fractures more than placebo. ${ }^{10}$ Prevention can be classified as primary or secondary. Primary prevention attempts to protect individuals against the onset of osteoporosis, whereas secondary prevention treats individuals living with the disease. ${ }^{11}$ Treatments such as alendronate, risedronate and other oral medications such as oestrogen can prevent hip fractures more than placebo. Patients treated with alendronate and zoledronic acid had better efficacy in preventing hip fracture. On the other hand, zoledronic acid was reported to lead to an increased risk of adverse events than alendronate and placebo. ${ }^{12}$ The clinical issues that should be considered when treating patients with osteoporosis using bisphosphonates include: the choice of which type of bisphosphonates to use, monitoring to assure the medication is taken correctly, determining the time when these medications should be discontinued and the management of their side effects. ${ }^{13}$

Patient persistence and adherence to oral bisphosphonates can be assessed using real-world data. This can be derived from electronic health records, product and disease registries, claims and billing data and data gathered through personal devices. ${ }^{14}$ The International Society for Pharmacoeconomics and Outcomes Research defines persistence as the accumulation of time from initiation to discontinuation of therapy. ${ }^{15}$ Adherence/ compliance was defined as the extent to which a patient acts in accordance with the prescribed interval and dose as well as dosing regimen. Poor persistence and adherence to bisphosphonate therapy can significantly increase the risk of fracture and overall burden of osteoporosis. ${ }^{12}$ Thus it is important to quantify the prevalence of this in wider populations and consider potential factors that may influence this, such as patient characteristics.

Although previous systematic reviews have included some real-world data, the studies were not assessed for quality and did not examine the potential determinants of adherence and persistence. ${ }^{16} 17$ To the authors' knowledge, there is no contemporary review that focuses on oral bisphosphonate medication adherence and persistence among patients with osteoporosis in the realworld. Understanding patient persistence and adherence to oral bisphosphonates and their determinants may be used to reduce the risk of fractures in the treatment of osteoporosis. ${ }^{1}$ Therefore, this current systematic review addresses two objectives. First, it summarises patient persistence and adherence to oral bisphosphonates in real-world settings. Second, it identifies determinants that may affect real-world adherence and persistence.

\section{METHODS}

This systematic review was conducted in accordance to the Preferred Reporting Items for Systematic Reviews and Meta-Analysis guideline, a technique that addresses the eligibility, data sources, selection of studies, data extraction and data analysis. ${ }^{18}$ The review was registered on PROSPERO, with registration number CRD: 42017059894.

\section{Data sources}

We searched the Allied and Complementary Medicine Database, Cumulative Index to Nursing and Allied Health Literature, MEDLINE; Database of Abstracts of Reviews of Effects, Health Technology Assessment database and the Centre for Reviews and Dissemination database up to April 2018. The search terms used were persist* OR adher* OR non-adher* OR complian* OR discontinu* OR prescri* OR pattern* OR gap* (TITLE) AND Osteoporo* OR Osteopen* OR (Bone AND loss) ORAlendron* OR Etidron* OR Ibandron* OR Risedron* OR bisphosphonat* (TITLE). All search results were exported into EndNote Web (Thomas Reuter, CA, USA) bibliography software.

\section{Inclusion criteria}

Prospective and retrospective observational studies that used prescription claims databases or patient electronic medical records or to investigate persistence and adherence to oral bisphosphonate medications in the treatment of osteoporosis or osteopenia in human adults were included. Eligible studies were required to have an abstract and article published in the English language, within a peer-reviewed source. Studies conducted in any geographical location were permitted. Randomised controlled trials (RCTs), systematic reviews, narrative literature reviews and conference papers were excluded. Further exclusion criteria were as follows; abstract unavailable, studies not yet fully completed, single case studies / reports, observational studies drawing persistence/adherence data from patient or general practitioner survey, prospective studies designed to observe changes in adherence via the introduction of a non-typical intervention or adjunct and studies containing patients aged $<18$ years.

\section{Study selection}

Duplicates were removed electronically and manually. Two independent researchers (PS and TG) were involved in screening the title and abstract of each study. Full-text articles were obtained and were excluded if they did not meet the inclusion criteria. Any disagreement in study selection was resolved through discussion and consultation with other members of the project team (GY and FF), where necessary. During screening, open-label extension studies of RCTs were excluded. It was considered that this design may not generate data that truly reflected a realworld pattern of persistence and adherence. Studies using data from electronic medical records, outside of addition to large-scale databases were also included provided 
persistence and adherence data were determined from prescription claims data rather than extracted from supplemental patient interviews, patient-supplied pill counts or subjective questionnaires. The literature search was supplemented by screening the reference lists of included articles for further eligible studies.

\section{Data extraction and study quality assessment}

Determinants (factors that may affect or be associated with) persistence or adherence were extracted from eligible studies, including patient characteristics such as age and sex, medication, population location, time-frame of data collection and length of follow-up. The quality of the studies was assessed using the Newcastle-Ottawa quality assessment scale (NOS) for cohort studies. ${ }^{19}$ The NOS contains eight items, categorised into three dimensions including selection and comparability. The maximum score of NOS is nine. However, some questions within the NOS were not applicable across the eligible studies dependent on their study design. In this instance, authors determined and adjusted the NOS score to account for this, rating studies only on the number of questions that were applicable and relevant.

\section{Data analysis}

A descriptive analysis of extracted results is presented. No meta-analysis was carried out due to heterogeneity of reporting methodologies and calculations of adherence and persistence across studies.

\section{Patient and public involvement}

Patients and the general public were not involved in this study.

\section{RESULTS}

The literature search identified 540 potential articles, of which 517 were remained after the removal of duplicates. After the titles and abstracts of these publications were screened, 143 references were identified as potentially relevant and retrieved in full text. Of these, 89 were included in review (figure 1). The methodological quality of the included studies is presented (table 1). All the included studies scored between six to eight on the NOS.

The geographical location of the studies included were: USA $(n=37)$, Canada $(n=7)$, UK $(n=6)$, Netherlands $(n=6)$, Denmark $(n=5)$, Italy $(n=5)$, Germany

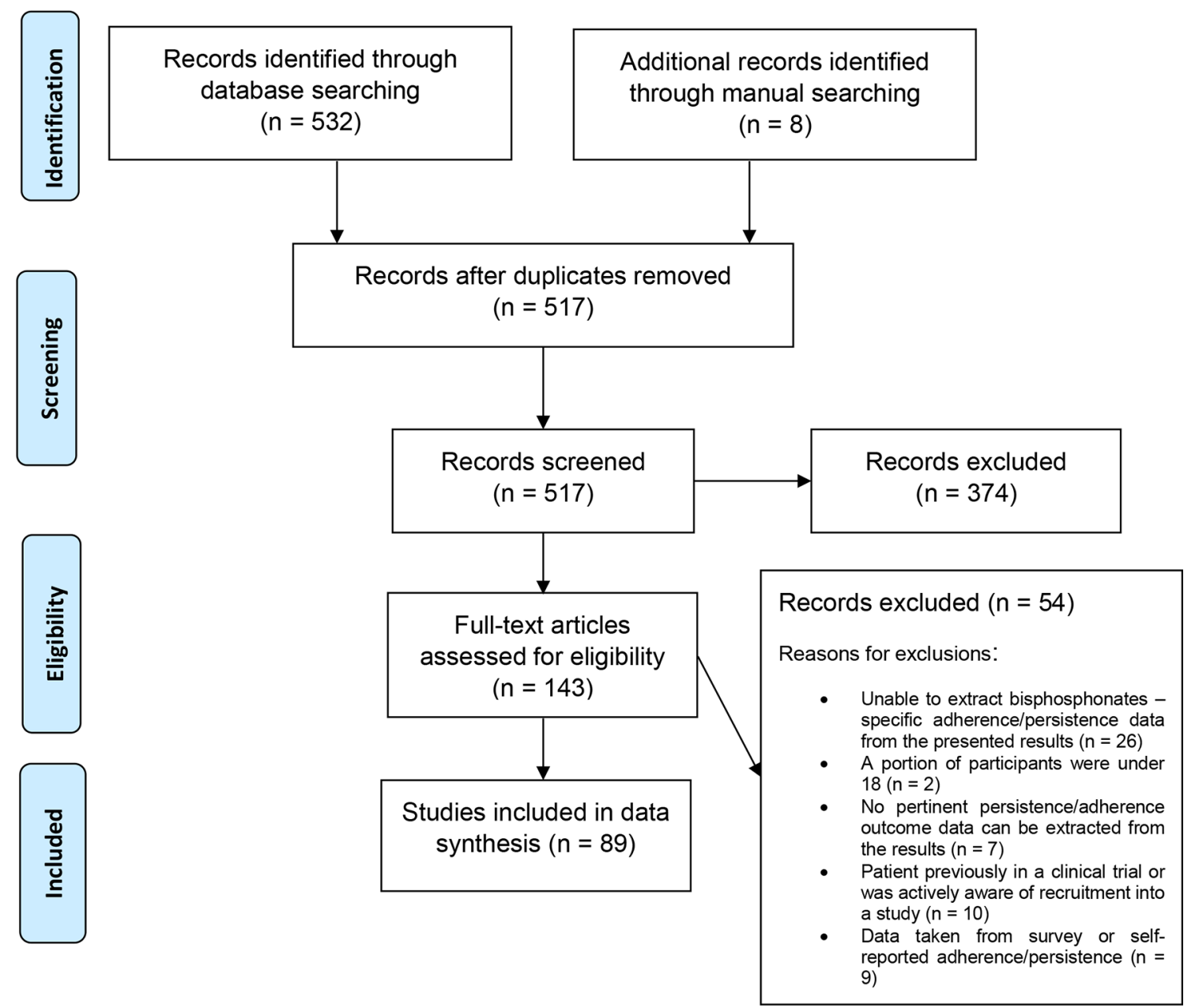

Figure 1 The preferred reporting for systematic reviews and meta-analyses diagram representing the systematic literature search. $^{94}$ 
Table 1 Summary of studies included in this review

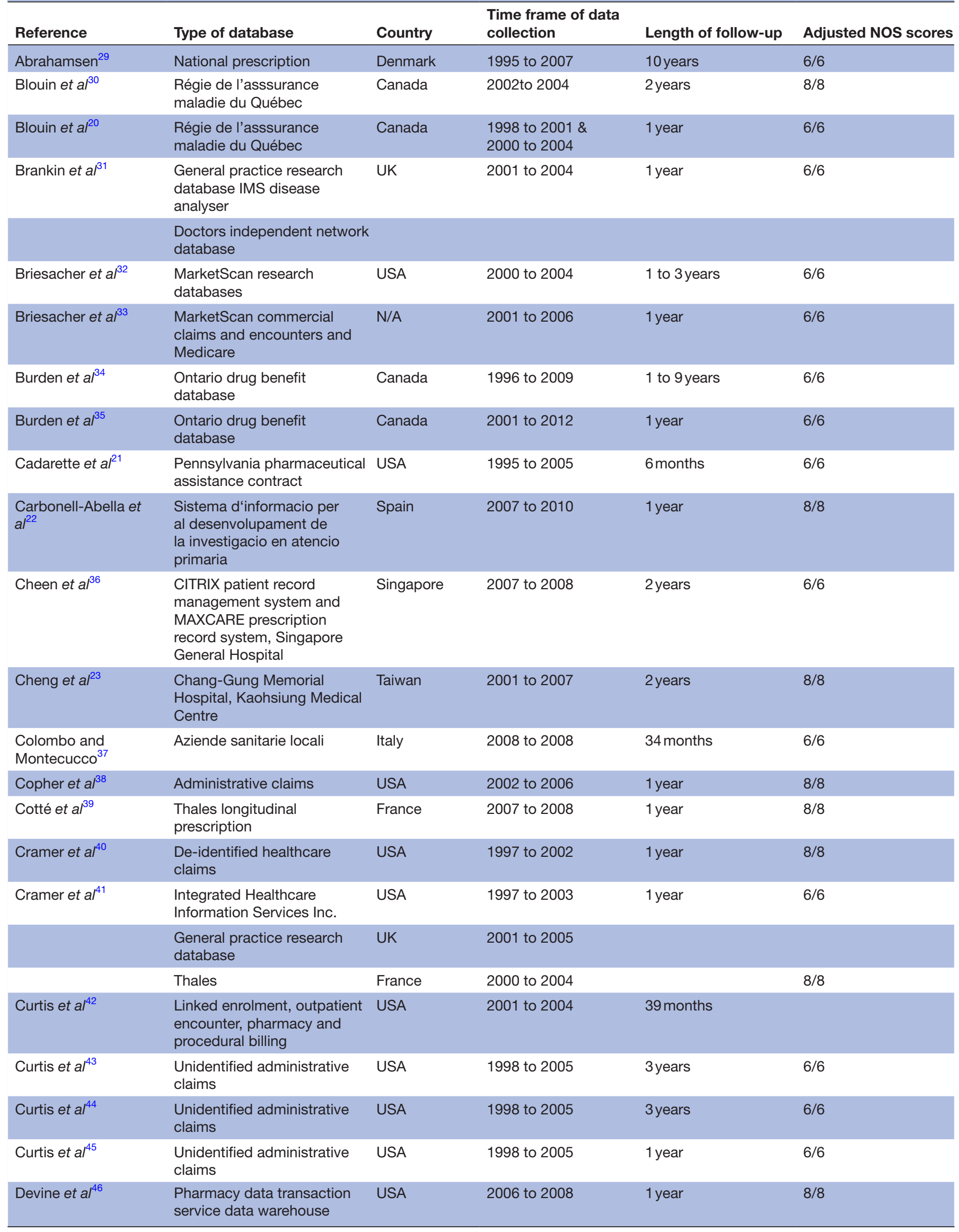


Table 1 Continued

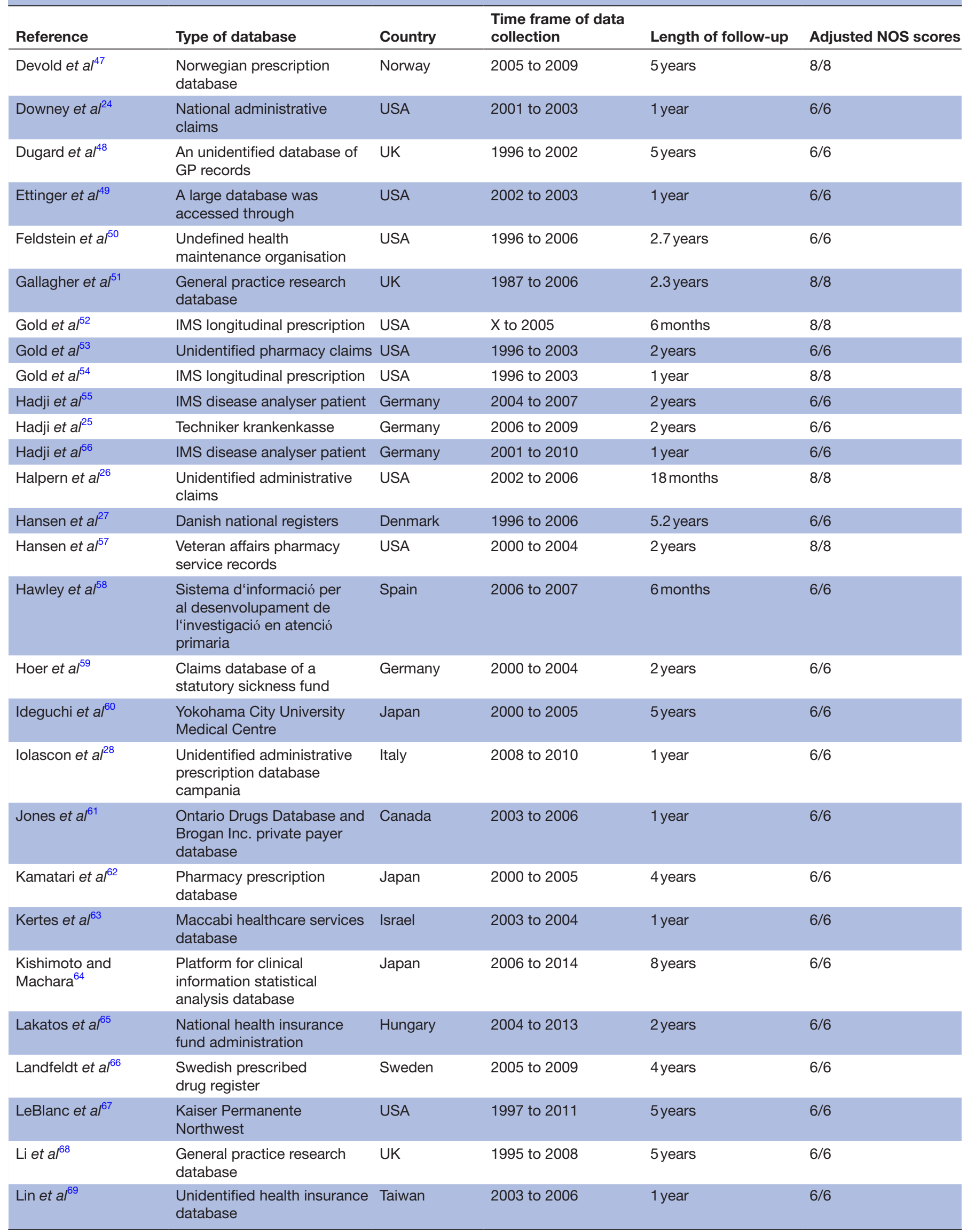


Table 1 Continued

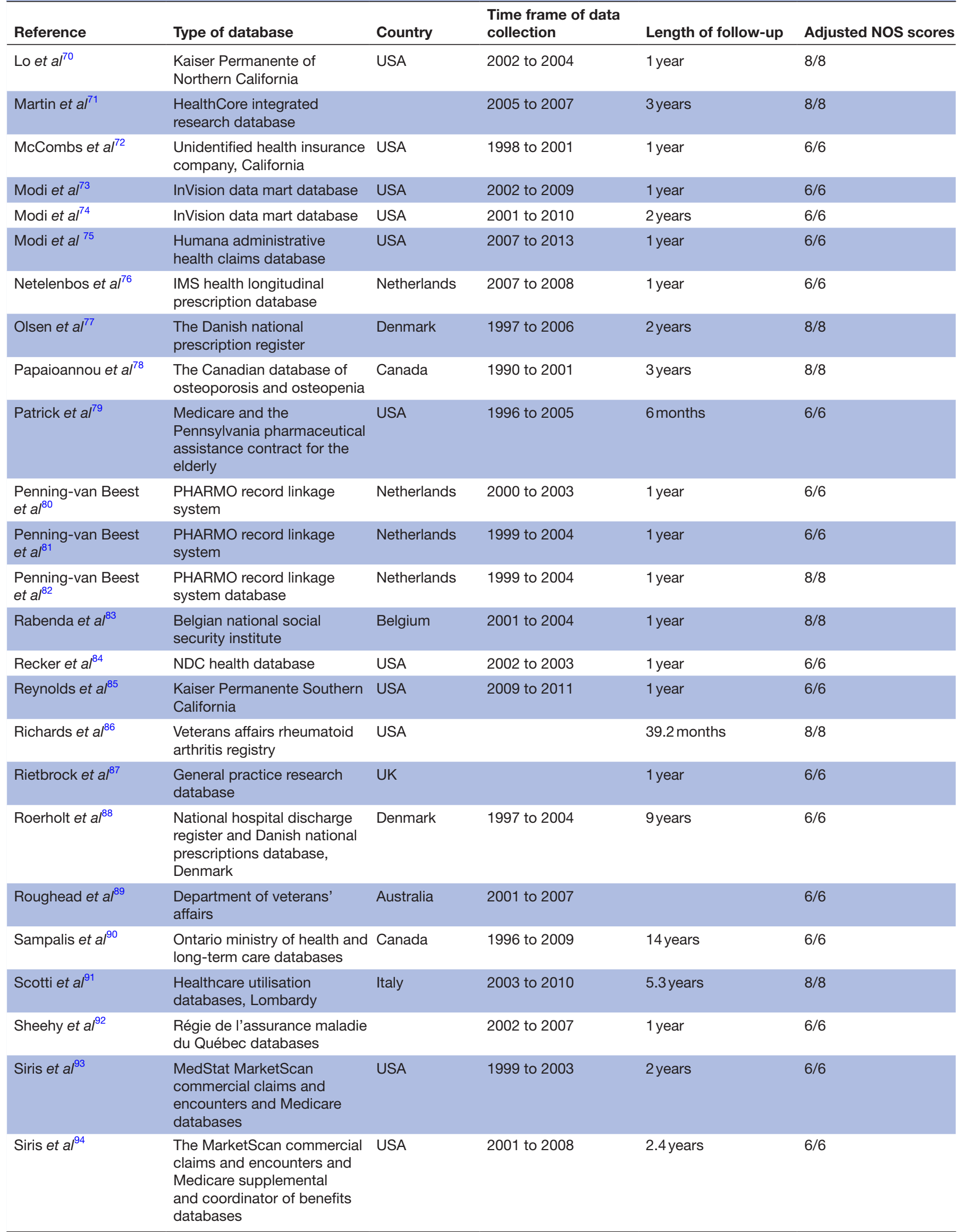


Table 1 Continued

\begin{tabular}{|c|c|c|c|c|c|}
\hline Reference & Type of database & Country & $\begin{array}{l}\text { Time frame of data } \\
\text { collection }\end{array}$ & Length of follow-up & Adjusted NOS scores \\
\hline Soong et $a l^{95}$ & $\begin{array}{l}\text { National health insurance } \\
\text { research database }\end{array}$ & Taiwan & 2004 to 2006 & 1 year & $6 / 6$ \\
\hline Ström ${ }^{96}$ & $\begin{array}{l}\text { Swedish prescribed drug } \\
\text { register }\end{array}$ & Sweden & 2005 to 2009 & 4 years & $6 / 6$ \\
\hline Sunyecz et al ${ }^{97}$ & $\begin{array}{l}\text { Thomson healthcare, } \\
\text { MarketScan commercial } \\
\text { claims and encounters } \\
\text { and MarketScan } \\
\text { Medicare, supplemental } \\
\text { and coordination of benefits } \\
\text { databases }\end{array}$ & USA & 2000 to 2002 & 3 years & $6 / 6$ \\
\hline Tafaro et a $\left.\right|^{98}$ & $\begin{array}{l}\text { General practitioner } \\
\text { databases }\end{array}$ & Italy & 2001 to 2007 & 300 days & $6 / 6$ \\
\hline Wang et $a l^{101}$ & $\begin{array}{l}\text { Centres for Medicare and } \\
\text { Medicaid services }\end{array}$ & USA & 2006 to 2010 & 5 years & $6 / 6$ \\
\hline Weiss et $a l^{102}$ & $\begin{array}{l}\text { IMS longitudinal prescription } \\
\text { database }\end{array}$ & & 2004 to 2006 & 1 year & $6 / 6$ \\
\hline Weycker et al ${ }^{103}$ & $\begin{array}{l}\text { PharMetrics patient-centric } \\
\text { database }\end{array}$ & USA & 1998 to 2003 & 5.5 years & $6 / 6$ \\
\hline Weycker et al ${ }^{104}$ & $\begin{array}{l}\text { Health alliance plan of Henry } \\
\text { Ford Health System }\end{array}$ & USA & 2002 to 2007 & 27.1 months & $6 / 6$ \\
\hline Yeaw et $a 1^{105}$ & $\begin{array}{l}\text { PharMetrics patient-centric } \\
\text { database }\end{array}$ & USA & 2005 to 2005 & 1 to 2 years & $6 / 6$ \\
\hline Yood et al ${ }^{106}$ & $\begin{array}{l}\text { Unidentified health } \\
\text { maintenance organisation }\end{array}$ & USA & 1998 to 1999 & 18 months & $6 / 6$ \\
\hline
\end{tabular}

GP, general practitioner; NOS, Newcastle-Ottawa quality assessment scale; N/A, not reported.

$(n=5)$, Japan $(n=3)$, Taiwan $(n=3)$, Spain $(n=2)$, France $(\mathrm{n}=2)$ and single studies from Singapore, Norway, Israel, Hungary, Sweden, Belgium and Australia (see table 1). The mean age of patients included within the studies ranged between 53 to 80.8 years and the length of follow-up ranges between 3 months and 14 years. The length of follow-up of the included studies could be stratified to 6 months $(n=4)$, 1 year $(n=37), 2$ years $(n=16)$ and $\geq 3$ years $(n=32)$.

The medications included in this review as primary or secondary prevention in the treatment of osteoporosis are alendronate, etidronate, risedronate, ibandronate, clodronate, zoledronate, alendronate +vitamin D and risedronate +calcium. Some of the included studies also looked at pamidronate and raloxifene. ${ }^{20-28}$ In order to measure the persistence and adherence of patients to these medications the included studies have used different techniques. ${ }^{20-108}$ Persistence was measured based on the length of treatment without a gap in refills (table 2). The permissible gap between medication refills the included studies used was typically 30 days, and sometime 60 or
90 days. On the other hand, adherence was measured by calculating the medication possession ratio (MPR), ${ }^{20} 23-25$ 293233 36-48 50 52 545557596467 69-71 74-77 81-84 8790 93-95 9798101104 105108 and proportion of days covered (PDC). ${ }^{21} 357991105$ MPR means the number of days' supply of medication received divided by the length of the follow-up period. ${ }^{109}$

\section{Persistence}

Sixty studies assessing persistence using real-world data from 4070739 patients were identified (table 2). The overall mean persistence of oral bisphosphonates at 6 months, ${ }^{3940425258616568747678839092104} 1$ year, ${ }^{21-25} 2831$ 34-36 39-42 48 $495153555659-687078808387909295991001031051082$ years $^{25} 2730343642485356596064-66689094100103$ and 3 years ranged from $34.8 \%$ to $71.3 \%, 17.65 \%$ to $74.80 \%, 12.9 \%$ to $60.60 \%$ and $21.0 \%$ to $40.0 \%$ respectively (figure 2 ). The 6 month persistence of ibandronate, ${ }^{39526568}$ alendronate $^{426165687892}$ and risedronate, ${ }^{395261656892}$ ranged from $29 \%$ to $57.3 \%, 45.5 \%$ to $79 \%$ and $46.8 \%$ to $77 \%$, respectively. Thirteen studies reported 1 year persistence data for alendronate $(12.6 \%$ to $70.1 \%), 2224284262656668789299$ 


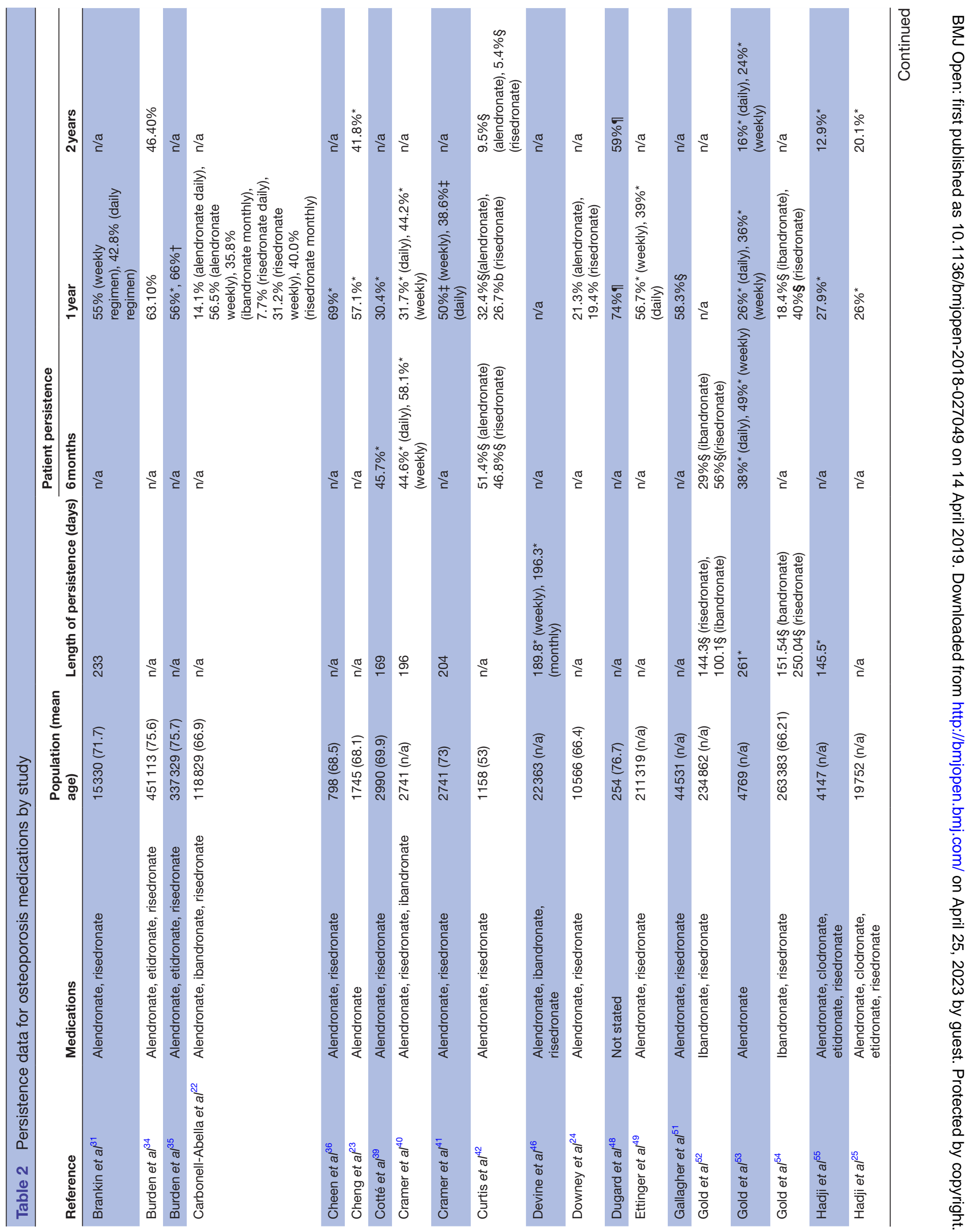




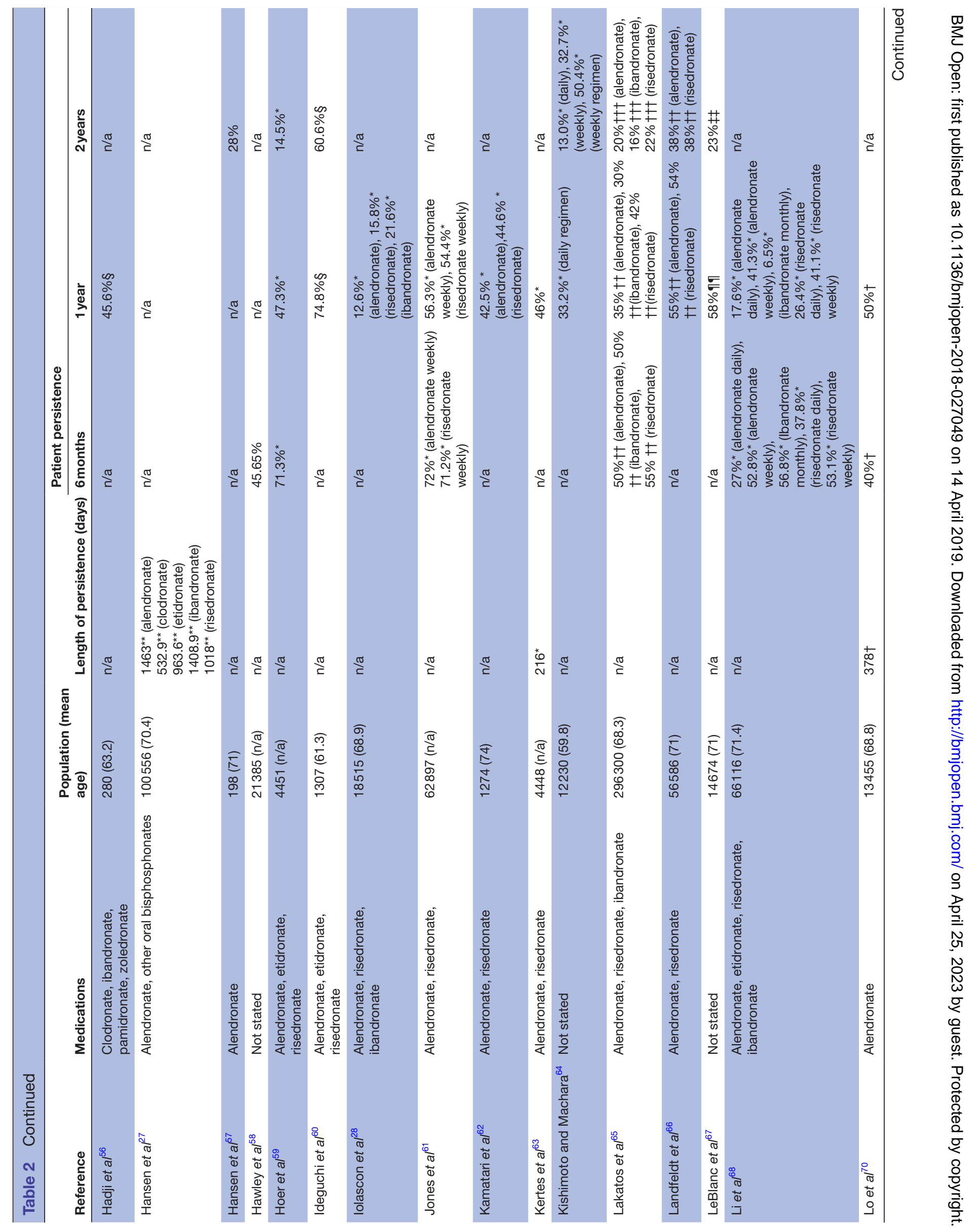




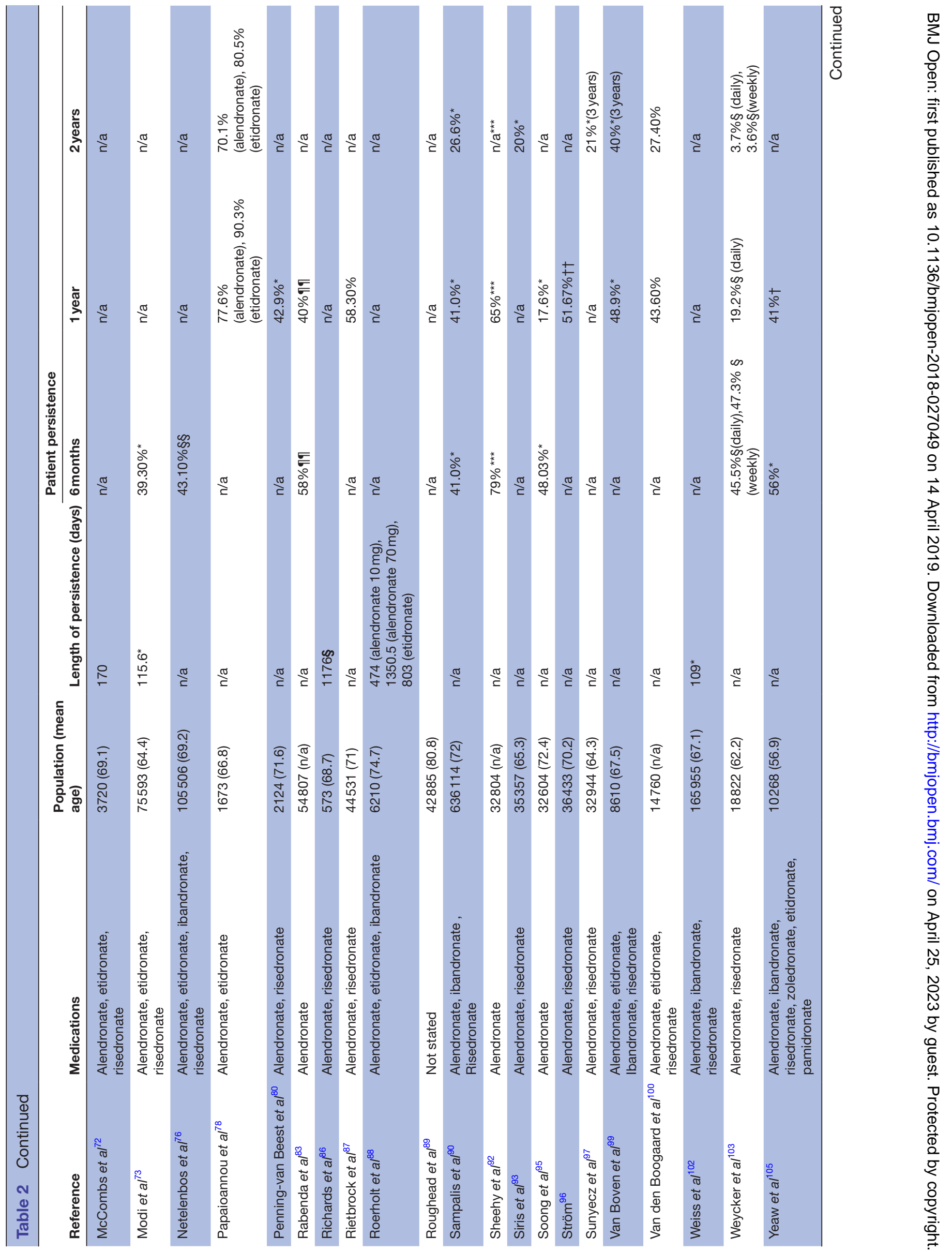




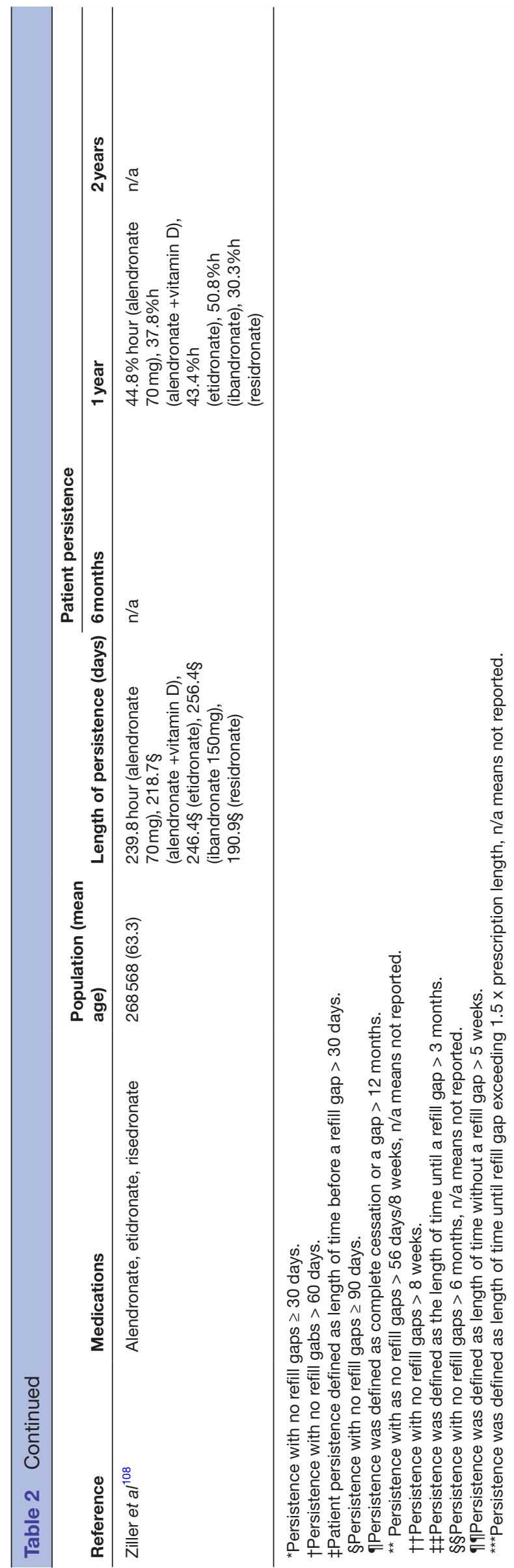

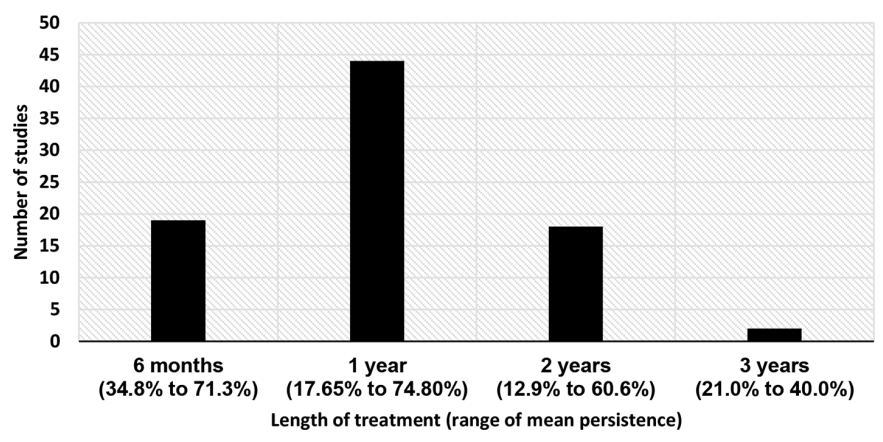

Figure 2 Frequency for reported range of mean persistence per length of treatment.

108 risedronate $(15.8 \% \text { to } 68.0 \%)^{22} 242842546163656892100$ 108 and ibandronate (18.4\% to 58.5\%)\%). ${ }^{22} 2854656899108$

Out of 19 studies, ${ }^{25} 2730343642485356596064-66689094100$ 103 that reported the 2 year persistence of oral bisphosphonates, more than $70 \%$ of them found the proportion of patients persistent to be $<30 \%$. A 3 year persistence of $21 \%$ and $40 \%$ was reported by two studies. ${ }^{97} 99$

\section{Adherence}

We identified 55 studies that measured adherence based on real-world data from 4033731 patients in different countries (table 3 ). The minimum length of follow-up period used in the included studies to measure MPR and PDC was 3 months. The 3 month follow-up study reported the proportion of adherent patients to alendronate and risedronate as $72.8 \%$ (daily) and $80 \%$ (weekly). ${ }^{80} \mathrm{Few}$ studies reported MPR that ranged between $55.6 \%$ and $90 \%$ for 6 months follow-up (table 3). ${ }^{215259} 79$ Across all studies that reported MPR at 1 year, the proportion of patients adherent to medication varied from $31.7 \%$ to $72.0 \%$.23 $24272832-343638-42444648535961646971737476808494$ 95105108

Across six studies adherence at 2 years was less than that of adherence at 1year, ranging from $34.5 \%$ to $47.9 \% .{ }^{23} 3243597174$ Parallel to this, six studies reported the proportion of patients who achieved MPR $\geq 80 \%$ at 3 years varied between $23 \%$ and $47.9 \% .^{29} 3243444871$ Overall, adherence rates to oral bisphosphonates reduced overtime within and across studies.

\section{Determinants of persistence and adherence}

Out of the 89 studies, 55 reported at least one potential determinant of persistence and adherence to oral bisphosphonates (online supplementary file 1). The potential determinants of persistence and adherence reported in the studies included geographic residence, ${ }^{30}$ prior bone mineral density (BMD) test, ${ }^{20} 30394870$ chronic disease score,${ }^{30}$ hospitalisation, ${ }^{30518094}$ medication type and frequency, $22243138-4345464951-54636478$ 8081838691929799100102103107108 age, $273638404246-495153$ 616369707376778081878991939499102104107 history of fractures, ${ }^{36} 5159727377818894103$ race/ethnicity ${ }^{38}$ and number of co-medication. ${ }^{40} 6977889193$ In addition to these, glucocorticoid, ${ }^{4370100}$ gender, ${ }^{51} 6062697677889299$ education status, ${ }^{47} 7786$ income,${ }^{47}$ marital status,${ }^{47}$ history of 
Table 3 Adherence data for osteoporosis medications

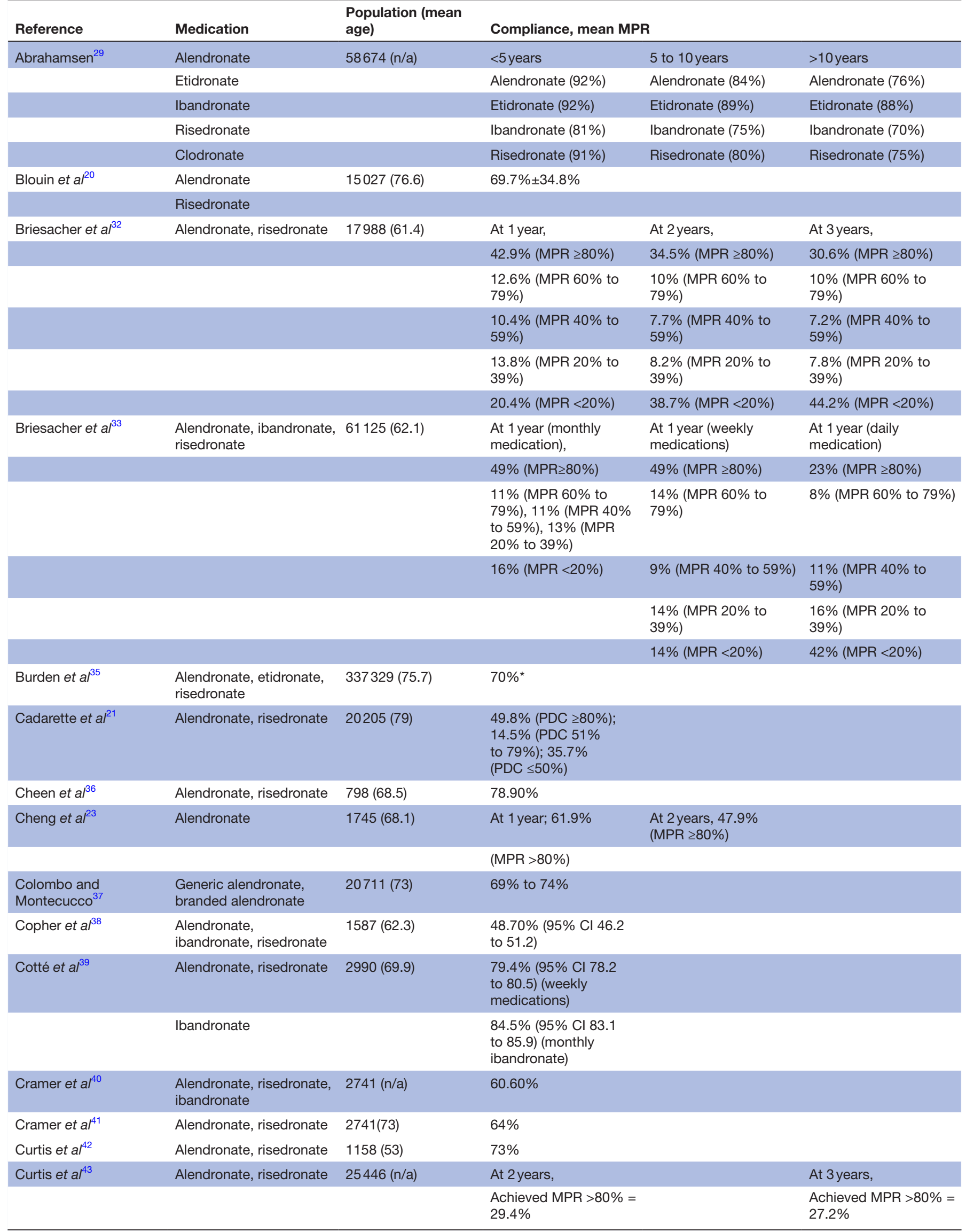


Table 3 Continued

\begin{tabular}{|c|c|c|c|c|c|}
\hline \multirow[t]{2}{*}{ Reference } & \multirow[t]{2}{*}{ Medication } & \multirow[t]{2}{*}{$\begin{array}{l}\text { Population (mean } \\
\text { age) }\end{array}$} & \multicolumn{3}{|l|}{ Compliance, mean MPR } \\
\hline & & & $\begin{array}{l}\text { Achieved MPR }<50 \%= \\
34.9 \%\end{array}$ & & $\begin{array}{l}\text { Achieved MPR }<50 \%= \\
39.4 \%\end{array}$ \\
\hline \multirow[t]{2}{*}{ Curtis et $a l^{45}$} & Alendronate & 101038 (n/a) & $\begin{array}{l}\text { Achieving MPR > } 80 \% \\
=44 \%\end{array}$ & & \\
\hline & \multicolumn{2}{|l|}{ Ibandronate, risedronate } & & & \\
\hline Devine et $a l^{46}$ & $\begin{array}{l}\text { Alendronate, ibandronate, } \\
\text { risedronate }\end{array}$ & $22363(n / a)$ & $62 \%$ & & \\
\hline Devold et $a l^{47}$ & Alendronate & 7610 (66.6) & $\begin{array}{l}\text { Achieving MPR } \geq 80 \% \\
=45.5 \%\end{array}$ & & \\
\hline \multirow[t]{2}{*}{ Downey et $a l^{24}$} & Alendronate, risedronate & $10566(66.4)$ & $60.7 \%$ (alendronate) & & \\
\hline & & & $58.4 \%$ (risedronate) & & \\
\hline \multirow[t]{2}{*}{ Dugard et $a l^{48}$} & Not stated & $254(76.7)$ & At 1 year, & At 3 years, & $\begin{array}{l}\text { At } 5 \text { years, achieving } \\
\text { MPR } \geq 80 \%=23 \%\end{array}$ \\
\hline & & & $\begin{array}{l}\text { Achieving MPR } \geq 80 \% \\
=44 \%\end{array}$ & $\begin{array}{l}\text { Achieving MPR } \geq 80 \% \\
=42 \%\end{array}$ & \\
\hline Feldstein et $a l^{50}$ & $\begin{array}{l}\text { Alendronate, ibandronate, } \\
\text { risedronate }\end{array}$ & $1829(72)$ & $60 \%$ & & \\
\hline \multirow[t]{2}{*}{ Gold et $a l^{52}$} & Ibandronate, risedronate & 234862 (n/a) & 83.3\% (risedronate) & $79 \%$ (risedronate) & \\
\hline & & & 78.5\% (ibandronate) & & \\
\hline \multirow[t]{2}{*}{ Gold et al ${ }^{53}$} & Ibandronate, risedronate & $263383(66.21)$ & $74.68 \%$ (ibandronate) & & \\
\hline & & & $80.15 \%$ (risedronate) & & \\
\hline \multirow[t]{2}{*}{ Hadji et $a l^{55}$} & $\begin{array}{l}\text { Alendronate, clodronate, } \\
\text { etidronate, risedronate }\end{array}$ & 4147 (n/a) & $\begin{array}{l}\text { Achieving MPR } \geq 80 \% \\
=66.3 \%\end{array}$ & & \\
\hline & & & $\begin{array}{l}\text { Achieving MPR <80\% } \\
=22.7 \%\end{array}$ & & \\
\hline \multirow[t]{3}{*}{ Halpern et $a l^{26}$} & $\begin{array}{l}\text { Alendronate, ibandronate, } \\
\text { risedronate }\end{array}$ & 21655 (63.3) & At 6 months, & & At 18 months, \\
\hline & & & $\begin{array}{l}76 \% \text { (commercially } \\
\text { insured) }\end{array}$ & & $\begin{array}{l}59 \% \text { (commercially } \\
\text { insured) }\end{array}$ \\
\hline & & & $\begin{array}{l}68 \% \text { (Medicare } \\
\text { advantage) }\end{array}$ & & $\begin{array}{l}53 \% \text { (Medicare } \\
\text { advantage) }\end{array}$ \\
\hline \multirow[t]{2}{*}{ Hansen et $a l^{57}$} & Alendronate & $198(71)$ & At 12 months, & & At 2 years, \\
\hline & & & $\begin{array}{l}\text { Achieving MPR } \geq 80 \% \\
=59 \%\end{array}$ & & $\begin{array}{l}\text { Achieving MPR } \geq 80 \% \\
=54 \%\end{array}$ \\
\hline \multirow[t]{2}{*}{ Hoer et $a l^{59}$} & $\begin{array}{l}\text { Alendronate, etidronate, } \\
\text { risedronate }\end{array}$ & $4451(n / a)$ & At 6 months, & & At 1 year, \\
\hline & & & $\begin{array}{l}\text { Achieving MPR } \geq 80 \% \\
=58.6 \%\end{array}$ & & $\begin{array}{l}\text { Achieving MPR } \geq 80 \%= \\
46.25 \%\end{array}$ \\
\hline \multirow{4}{*}{$\begin{array}{l}\text { Kishimoto and } \\
\text { Machara }^{64}\end{array}$} & Not stated & $12230(62)$ & At 1 year, & & At 5 years, \\
\hline & & & $38.6 \%$ (daily) & & $20.8 \%$ (daily) \\
\hline & & & 70.6\% (weekly) & & $60.9 \%$ (weekly) \\
\hline & & & $77.7 \%$ (monthly) & & \\
\hline LeBlanc et $a l^{67}$ & Not stated & $14674(71)$ & $94 \%$ & & \\
\hline Lin et $a l^{69}$ & Alendronate & $8936(74)$ & $60.20 \%$ & & \\
\hline Lo et $a l^{70}$ & Alendronate & $13455(68.8)$ & $93 \%$ & & \\
\hline \multirow[t]{4}{*}{ Martin et $a l^{71}$} & $\begin{array}{l}\text { Alendronate, ibandronate, } \\
\text { risedronate }\end{array}$ & 45939 (59.6) & At 1 year, & At 2 years, & At 3 years, \\
\hline & & & $58 \%$ (alendronate) & $48 \%$ (alendronate) & $42 \%$ (alendronate) \\
\hline & & & $58 \%$ (ibandronate) & $50 \%$ (ibandronate) & $46 \%$ (ibandronate) \\
\hline & & & $57 \%$ (isedronate) & 47\% (risedronate) & 43\% (risedronate) \\
\hline Modi et $a l^{75}$ & $\begin{array}{l}\text { Alendronate, ibandronate, } \\
\text { risedronate }\end{array}$ & $37886(74.1)$ & $\begin{array}{l}\text { Achieving MPR } \geq 80 \% \\
=31.7 \%\end{array}$ & & \\
\hline Netelenbos et $a l^{76}$ & Alendronate & 105506 & $91 \%$ & & \\
\hline
\end{tabular}


Open access

Table 3 Continued

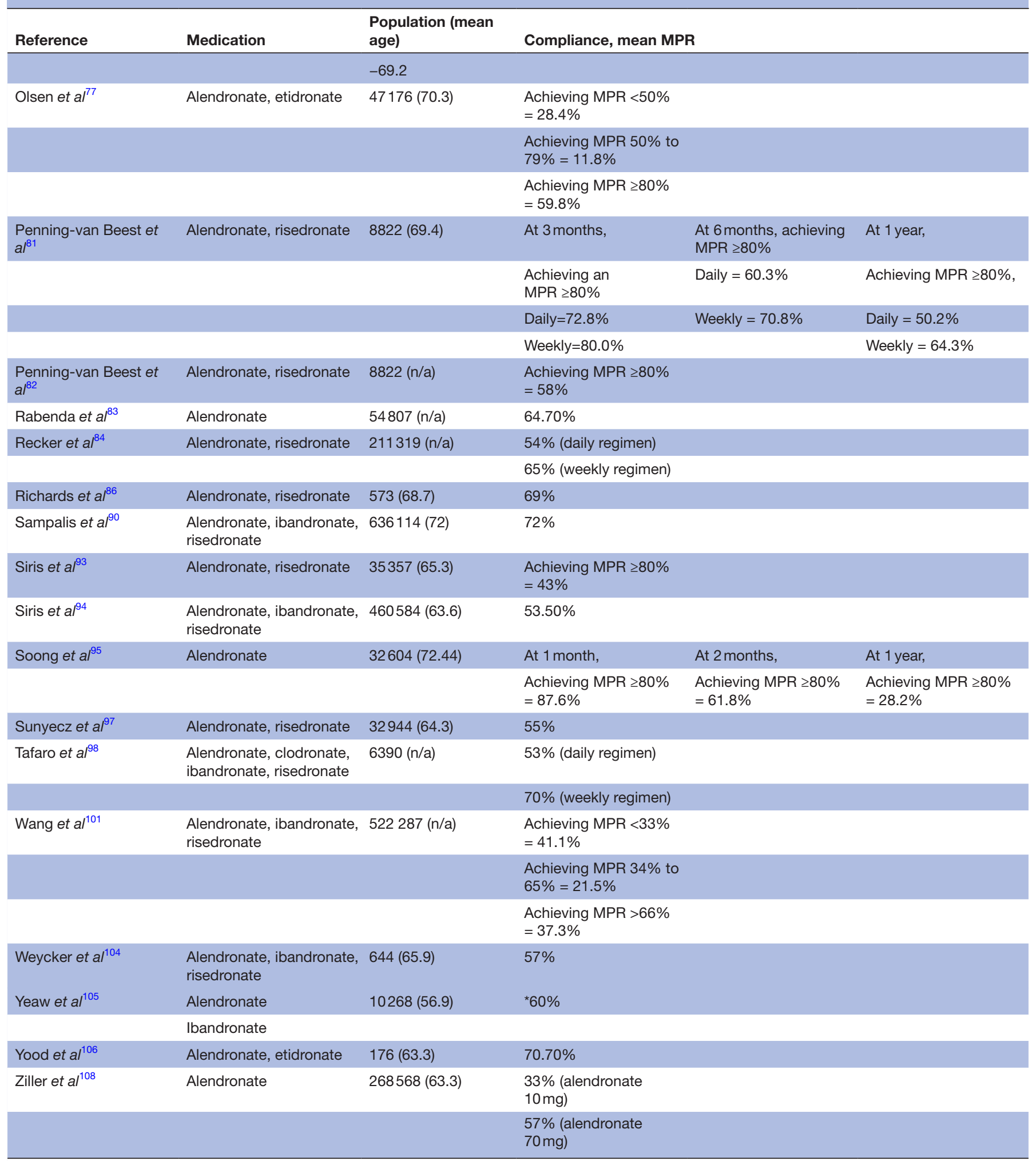

${ }^{*}$ Mean Proportion of Days Covered (PDC).

MPR, medication possession ratio.

upper gastrointestinal problems,,${ }^{51}$ tobacco use,${ }^{27}$ rheumatoid arthritis, ${ }^{62} 86$ national insurance, ${ }^{63}$ hormone replacement therapy, ${ }^{70}$ clinical service use ${ }^{79}$ mental disorder, ${ }^{104}$ diabetes and co-payments, ${ }^{102} 104$ were mentioned as determinants of persistence and adherence. The relationship of these determinants to patients' persistence and adherence to medication is described below. 
In the studies that have reported prior BMD test as a determinant factor, patients who have undergone prior BMD test before receiving medications have higher persistence and adherence compared with those who have not. ${ }^{20} 30394870$ Moreover, weekly oral bisphosphonates medication users had significantly higher mean persistence than those daily users. ${ }^{22} 243138-4345464951-54$ 6364788081838691929799100102103107108

Before decreasing at ages 80 and above a number of studies have reported higher persistence and adherence at older ages than younger ages. ${ }^{27} 3638404246-495153616369707376778081878891$ 939499102104107

being received at baseline was associated with a marginally greater risk of discontinuing 406977889193 Cornally greater risk of discontinuing. Compared with male users of oral BP medications, female users were at lower odds of achieving adherence..$^{516062697677889299}$

\section{DISCUSSION}

This review summarises patient persistence and adherence and their determinants with oral bisphosphonates in the treatment of osteoporosis in real-world settings. A total of 89 studies, undertaken in the USA, Canada, Europe, Asia and Australia were used to collect information on the real-world persistence and adherence with oral bisphosphonates for the treatment of osteoporosis. The analyses of these data suggest that patient persistence and adherence rates to oral bisphosphonates reduced over time following initial prescription. For example, the overall mean persistence of oral bisphosphonates at 6 months, 1 year and 2 years post-index ranged from $34.8 \%$ to $71.3 \%, 17.6 \%$ to $74.8 \%$ and $12.9 \%$ to $60.6 \%$, respectively. Dosing frequency appeared to affect persistence, with 6 month persistence of oral bisphosphonates with daily, weekly and monthly medication ranging between $27 \%$ and $45.5 \%, 45.7 \%$ and $72 \%$ and $56.8 \%$ and $56.8 \%$, respectively. The findings of this current review were similar to that reported by Cramer et al who found 1 year persistence to bisphosphonate therapy ranged between $17.9 \%$ to $78.0 \%{ }^{16}$ The review by Cramer and colleagues also reported that patients prescribed weekly oral bisphosphonates exhibited better persistence than those prescribed daily oral bisphosphonates $(35.7 \%$ to $69.7 \%$ vs $26.1 \%$ to $55.7 \%$ ).

High adherence rates of oral bisphosphonates may also lead to the most effective way of improving the benefit of these medications. For example, evidence suggests that the 2year probability of fracture in females with osteoporosis may only begin to decrease as MPR exceeds $50 \%$, and notably so after it exceeds $75 \% .{ }^{93}$ Across all included studies that reported MPR at 6and 12 months, the proportion of patients adherent to medication varied from $31.7 \%$ to $72.0 \%$ and $55.6 \%$ to $90.0 \%$, respectively. Mean medication possession ratio ranged from 0.59 to 0.81 (weekly) and 0.46 to 0.64 (daily), which are similar to the findings of a previous systematic review. ${ }^{16}$

Poor persistence and adherence to oral bisphosphonates, particularly in chronic asymptomatic disease such as osteoporosis, may compromise the clinical and economic effects of this class of medications among patients. In this review, 32 studies reported $\geq 50 \%$ persistence and adherence of alendronate, risedronate, etidronate and clodronate. $^{23252634-373941424651536061666771767881-848792}$ 949598104106108

The remaining 57 studies reported $\leq 50 \%$ of persistence or adherence. The variation of patient persistence and adherence to medication across studies may be due to a number of factors and the healthcare system of the countries included within this review. Age 27 $3638404246-495153616369707376778081878991939499102104107$ and medication dosing and frequency $22243138-43454649$ 51-54636478 8081838691929799100102103107108 as a determinant factor of osteoporosis was reported by 29 and 32 studies, respectively. The studies included also indicated that older patients were more likely to achieve higher persistence and adherence to oral bisphosphonates and that daily users of oral bisphosphonates medications have lower persistence and adherence than weekly users. Strengths and limitations to this review are acknowledged by the authors. This review involved a systematic and rigorous search for studies relating to patient persistence and adherence using real-world data. Measuring adherence and persistence based on real-world data is beneficial as it captures the timelines and frequency of refilling and thus measures the continuity of medication use. ${ }^{10}$ Database-derived persistence and adherence assessment carries the advantage of being objective, quantifiable and simple. ${ }^{111}$ Despite these strengths, it is also important to consider the following limitations. First, the calculation of persistence and adherence across the studies was heterogeneous. As a result, it was not possible to inferentially compare these studies with each other. Second, the calculation of persistence and adherence provided in the studies may not be true values. For example, billing and coding errors may occur because data for these studies were obtained from patients in unrestricted 'real world clinical settings' primarily for administrative purposes. ${ }^{16}$ Collection and refilling of medication by patients does not guarantee that this medication was taken as directed, or at all. Third, although there are data for persistence and adherence of oral bisphosphonates from studies carried out from different geographical locations, it was not possible to identify any trends between the data and countries. Fourth, it is very difficult to capture the specific reasons for treatment discontinuation from prescription-driven or medical claim data rather than patient-derived data. The current review excluded data from randomised controlled trials to better reflect patient behaviour in the general osteoporosis population in reallife clinical practice. However, the exclusion of alternative designs such as open-label extension studies may infer an element of publication bias.

Additional studies are required to examine patient persistence or adherence in osteoporosis, including synthesis of qualitative studies to examine the reasons for discontinuation and real-world studies to examine healthcare resource use associated with osteoporosis 
medication in relation to adherence and persistence. As osteoporosis is a chronic disease, clinicians should not only take into consideration the efficacy and side effects of medications when deciding on treatment options, but also ensure that realistic patient expectations from treatment are set through patient education and counselling. The patient's lifestyle should also be considered as this is likely to impact adherence and persistence with osteoporosis therapy.

\section{CONCLUSIONS}

This review has summarised patient persistence and adherence to oral bisphosphonates from a quality assessed studies that have used real-world data. The findings of this review suggest that real-world patient persistence and adherence with oral bisphosphonates medications is often poor and drops notably over time following the initial prescription of oral medications. However, adherence and persistence tended to be better in older patients and in patients who were prescribed weekly, rather than daily medications. To maximise adherence and persistence to oral bisphosphonates, it is important to consider their possible determinants including medication type and frequency, hospitalisation, age, history of fractures, race/ ethnicity, gender, educational status and income as this may help to improve the health outcomes of patients with osteoporosis.

Contributors FF, PS, TG and GY were involved in conceptualisation and design of the study and critical review of the manuscript. FF, PS and TG performed the data extraction. All authors approved the final manuscript as submitted.

Funding The authors have not declared a specific grant for this research from any funding agency in the public, commercial or not-for-profit sectors.

Competing interests None declared.

Patient consent for publication Not required.

Provenance and peer review Not commissioned; externally peer reviewed.

Data sharing statement No additional data are available.

Open access This is an open access article distributed in accordance with the Creative Commons Attribution Non Commercial (CC BY-NC 4.0) license, which permits others to distribute, remix, adapt, build upon this work non-commercially, and license their derivative works on different terms, provided the original work is properly cited, appropriate credit is given, any changes made indicated, and the use is non-commercial. See: http://creativecommons.org/licenses/by-nc/4.0/.

\section{REFERENCES}

1. Woolf $A D$, Pfleger B. Burden of major musculoskeletal conditions. Bull World Health Organ 2003;81:646-56.

2. Ross PD. Osteoporosis. Frequency, consequences, and risk factors. Arch Intern Med 1996;156:1399-411.

3. Olszynski WP, Shawn Davison K, Adachi JD, et al. Osteoporosis in men: epidemiology, diagnosis, prevention, and treatment. Clin Ther 2004;26:15-28.

4. Sinaki M. Postural Changes in Osteoporosis: Musculoskeletal Consequences. Non-pharmacological management of osteoporosis: Springer, Cham, 2017:207-17.

5. Orsini LS, Rousculp MD, Long SR, et al. Health care utilization and expenditures in the United States: a study of osteoporosis-related fractures. Osteoporos Int 2005;16:359-71.

6. Keen RW. Burden of osteoporosis and fractures. Curr Osteoporos Rep 2003;1:66-70.

7. Burge R, Dawson-Hughes B, Solomon DH, et al. Incidence and economic burden of osteoporosis-related fractures in the United States, 2005-2025. J Bone Miner Res 2007;22:465-75.
8. Lewiecki EM. Bisphosphonates for the treatment of osteoporosis: insights for clinicians. Ther Adv Chronic Dis 2010;1:115-28.

9. Ammann P, Rizzoli R. Bone strength and its determinants. Osteoporosis International 2003;14:13-18.

10. MacLean C, Newberry S, Maglione M, et al. Systematic review: comparative effectiveness of treatments to prevent fractures in men and women with low bone density or osteoporosis. Ann Intern Med 2008;148:197-213.

11. Iki M. [Primary, secondary and tertiary prevention of osteoporosis]. Clin Calcium 2006;16:1438-43.

12. Imaz I, Zegarra P, González-Enríquez J, et al. Poor bisphosphonate adherence for treatment of osteoporosis increases fracture risk: systematic review and meta-analysis. Osteoporos Int 2010;21:1943-51.

13. Diab DL, Watts NB. Bisphosphonates in the treatment of osteoporosis. Endocrinol Metab Clin North Am 2012;41:487-506.

14. Network for Excellence in Health Innovation. Network for excellence in health innovation (2015) Real world evidence: a new era for health care. innovation.http://www.nehi.net/writable/publication_files/file/ rwe issue brief final.pdf

15. Burrell $\mathrm{A}$, Wong $\mathrm{P}$, Ollendorf $\mathrm{D}$, et al. PHP46 Defining compliance/ adherence and persistence: ispor special interest working group. Value in Health 2005;8:A194-5.

16. Cramer JA, Gold DT, Silverman SL, et al. A systematic review of persistence and compliance with bisphosphonates for osteoporosis. Osteoporosis International 2007;18:1023-31.

17. Kothawala P, Badamgarav E, Ryu S, et al; Systematic review and meta-analysis of real-world adherence to drug therapy for osteoporosis. Elsevier: Mayo Clinic Proceedings, 2007:1493-501.

18. Moher D, Liberati A, Tetzlaff J, et al. Preferred reporting items for systematic reviews and meta-analyses: the PRISMA statement. PLoS Med 2009;6:e1000097.

19. Stang A. Critical evaluation of the Newcastle-Ottawa scale for the assessment of the quality of nonrandomized studies in metaanalyses. Eur J Epidemiol 2010;25:603-5.

20. Blouin J, Dragomir A, Fredette M, et al. Comparison of direct health care costs related to the pharmacological treatment of osteoporosis and to the management of osteoporotic fractures among compliant and noncompliant users of alendronate and risedronate: a population-based study. Osteoporos Int 2009;20:1571-81.

21. Cadarette SM, Solomon DH, Katz JN, et al. Adherence to osteoporosis drugs and fracture prevention: no evidence of healthy adherer bias in a frail cohort of seniors. Osteoporos Int 2011;22:943-54.

22. Carbonell-Abella C, Pages-Castella A, Javaid MK, et al. Early (1-year) discontinuation of different anti-osteoporosis medications compared: a population-based cohort study. Calcif Tissue Int 2015;97:535-41.

23. Cheng TT, Yu SF, Hsu CY, et al. Differences in adherence to osteoporosis regimens: a 2-year analysis of a population treated under specific guidelines. Clin Ther 2013;35:1005-15.

24. Downey TW, Foltz SH, Boccuzzi SJ, et al. Adherence and persistence associated with the pharmacologic treatment of osteoporosis in a managed care setting. South Med J 2006;99:570-5.

25. Hadji P, Klein S, Häussler B, et al. The bone evaluation study (BEST): patient care and persistence to treatment of osteoporosis in Germany. Int J Clin Pharmacol Ther 2013;51:868-72.

26. Halpern R, Becker L, lqbal SU, et al. The association of adherence to osteoporosis therapies with fracture, all-cause medical costs, and all-cause hospitalizations: a retrospective claims analysis of female health plan enrollees with osteoporosis. J Manag Care Pharm 2011;17:25-39.

27. Hansen C, Pedersen BD, Konradsen $\mathrm{H}$, et al. Anti-osteoporotic therapy in Denmark--predictors and demographics of poor refill compliance and poor persistence. Osteoporos Int 2013;24:2079-97.

28. Iolascon G, Gimigliano F, Orlando V, et al. Osteoporosis drugs in real-world clinical practice: an analysis of persistence. Aging Clin Exp Res 2013;25:137-41.

29. Abrahamsen B. Are long-term bisphosphonate users a reality? Dose years for current bisphosphonate users assessed using the danish national prescription database. Osteoporos Int 2013;24:369-72.

30. Blouin J, Dragomir A, Ste-Marie LG, et al. Discontinuation of antiresorptive therapies: a comparison between 1998-2001 and 2002-2004 among osteoporotic women. J Clin Endocrinol Metab 2007;92:887-94.

31. Brankin $\mathrm{E}$, Walker $\mathrm{M}$, Lynch $\mathrm{N}$, et al. The impact of dosing frequency on compliance and persistence with bisphosphonates among postmenopausal women in the UK: evidence from three databases. Curr Med Res Opin 2006;22:1249-56. 
32. Briesacher BA, Andrade SE, Yood RA, et al. Consequences of poor compliance with bisphosphonates. Bone 2007;41:882-7.

33. Briesacher BA, Andrade SE, Harrold LR, et al. Adoption of oncemonthly oral bisphosphonates and the impact on adherence. Am J Med 2010;123:275-80

34. Burden AM, Paterson JM, Solomon DH, et al. Bisphosphonate prescribing, persistence and cumulative exposure in Ontario, Canada. Osteoporos Int 2012;23:1075-82.

35. Burden AM, Paterson JM, Gruneir A, et al. Adherence to osteoporosis pharmacotherapy is underestimated using days supply values in electronic pharmacy claims data. Pharmacoepidemiol Drug Saf 2015;24:67-74.

36. Cheen MH, Kong MC, Zhang RF, et al. Adherence to osteoporosis medications amongst Singaporean patients. Osteoporos Int 2012;23:1053-60

37. Colombo GL, Montecucco CM. 'Generic vs brand originator alendronate: analysis of persistence and compliance in five Local Healthcare Units in the Lombardy Region of Italy.' Clinical cases in mineral and bone metabolism. The Official Journal Of The Italian Society Of Osteoporosis, Mineral Metabolism, And Skeletal Diseases, 2013;10:195.

38. Copher R, Buzinec P, Zarotsky V, et al. Physician perception of patient adherence compared to patient adherence of osteoporosis medications from pharmacy claims. Curr Med Res Opin 2010;26:777-85.

39. Cotté FE, Fardellone P, Mercier F, et al. Adherence to monthly and weekly oral bisphosphonates in women with osteoporosis. Osteoporos Int 2010;21:145-55.

40. Cramer JA, Amonkar MM, Hebborn A, et al. Compliance and persistence with bisphosphonate dosing regimens among women with postmenopausal osteoporosis. Curr Med Res Opin 2005;21:1453-60.

41. Cramer JA, Lynch NO, Gaudin AF, et al. The effect of dosing frequency on compliance and persistence with bisphosphonate therapy in postmenopausal women: a comparison of studies in the United States, the United Kingdom, and France. Clin Ther 2006;28:1686-94

42. Curtis JR, Westfall AO, Allison JJ, et al. Channeling and adherence with alendronate and risedronate among chronic glucocorticoid users. Osteoporos Int 2006;17:1268-74.

43. Curtis JR, Westfall AO, Cheng $\mathrm{H}$, et al. Risk of hip fracture after bisphosphonate discontinuation: implications for a drug holiday. Osteoporos Int 2008;19:1613-20.

44. Curtis JR, Westfall AO, Cheng $\mathrm{H}$, et al. Benefit of adherence with bisphosphonates depends on age and fracture type: results from an analysis of 101,038 new bisphosphonate users. J Bone Miner Res 2008;23:1435-41.

45. Curtis JR, Xi J, Westfall AO, et al. Improving the prediction of medication compliance: the example of bisphosphonates for osteoporosis. Med Care 2009;47:334-41.

46. Devine J, Trice S, Finney Z, et al. A retrospective analysis of extended-interval dosing and the impact on bisphosphonate compliance in the US Military Health System. Osteoporos Int 2012;23:1415-24

47. Devold HM, Furu K, Skurtveit S, et al. Influence of socioeconomic factors on the adherence of alendronate treatment in incident users in Norway. Pharmacoepidemiol Drug Saf 2012;21:297-304.

48. Dugard MN, Jones TJ, Davie MW. Uptake of treatment for osteoporosis and compliance after bone density measurement in the community. J Epidemiol Community Health 2010;64:518-22.

49. Ettinger MP, Gallagher R, MacCosbe PE. Medication persistence with weekly versus daily doses of orally administered bisphosphonates. Endocr Pract 2006;12:522-8.

50. Feldstein AC, Weycker D, Nichols GA, et al. Effectiveness of bisphosphonate therapy in a community setting. Bone 2009;44:153-9

51. Gallagher AM, Rietbrock S, Olson M, et al. Fracture outcomes related to persistence and compliance with oral bisphosphonates. $J$ Bone Miner Res 2008;23:1569-75.

52. Gold DT, Safi W, Trinh H. Patient preference and adherence: comparative US studies between two bisphosphonates, weekly risedronate and monthly ibandronate. Curr Med Res Opin 2006;22:2383-91.

53. Gold DT, Martin BC, Frytak JR, et al. A claims database analysis of persistence with alendronate therapy and fracture risk in post-menopausal women with osteoporosis. Curr Med Res Opin 2007;23:585-94.

54. Gold DT, Trinh H, Safi W. Weekly versus monthly drug regimens: 1 -year compliance and persistence with bisphosphonate therapy. Curr Med Res Opin 2009;25:1831-9.
55. Hadji P, Claus V, Ziller V, et al. GRAND: the German retrospective cohort analysis on compliance and persistence and the associated risk of fractures in osteoporotic women treated with oral bisphosphonates. Osteoporos Int 2012;23:223-31.

56. Hadji P, Ziller V, Kyvernitakis J, et al. Persistence with bisphosphonates in patients with metastatic breast cancer: a retrospective database analysis. J Cancer Res Clin Oncol 2013;139:1149-55.

57. Hansen KE, Swenson ED, Baltz B, et al. Adherence to alendronate in male veterans. Osteoporos Int 2008;19:349-56.

58. Hawley S, Javaid MK, Rubin KH, et al. Incidence and predictors of multiple fractures despite high adherence to oral bisphosphonates: a binational population-based cohort study. J Bone Miner Res 2016;31:234-44.

59. Höer A, Seidlitz C, Gothe H, et al. 'Influence on persistence and adherence with oral bisphosphonates on fracture rates in osteoporosis. '. Patient Preference and Adherence 2009;3:25-30.

60. Ideguchi $\mathrm{H}$, Ohno S, Hattori $\mathrm{H}$, et al. Persistence with bisphosphonate therapy including treatment courses with multiple sequential bisphosphonates in the real world. Osteoporos Int 2007;18:1421-7.

61. Jones TJ, Petrella RJ, Crilly R. 'Determinants of persistence with weekly bisphosphonates in patients with osteoporosis.'. The Journal Of Rheumatology 2008;35:1865-73.

62. Kamatari M, Koto S, Ozawa N, et al. Factors affecting longterm compliance of osteoporotic patients with bisphosphonate treatment and QOL assessment in actual practice: alendronate and risedronate. J Bone Miner Metab 2007;25:302-9.

63. Kertes J, Dushenat M, Vesterman JL, et al. Factors contributing to compliance with osteoporosis medication. Isr Med Assoc J 2008:10:207-13.

64. Kishimoto H, Maehara M. Compliance and persistence with daily, weekly, and monthly bisphosphonates for osteoporosis in Japan: analysis of data from the CISA. Arch Osteoporos 2015;10:231.

65. Lakatos P, Takács I, Marton I, et al. A retrospective longitudinal database study of persistence and compliance with treatment of osteoporosis in hungary. Calcif Tissue Int 2016;98:215-25.

66. Landfeldt E, Ström O, Robbins S, et al. Adherence to treatment of primary osteoporosis and its association to fractures--the Swedish Adherence Register Analysis (SARA). Osteoporos Int 2012;23:433-43.

67. LeBlanc ES, Rosales AG, Balasubramanian A, et al. Risk factors for fracture among current, persistent users of bisphosphonates. Osteoporos Int 2015;26:713-25.

68. Li L, Roddam A, Gitlin M, et al. Persistence with osteoporosis medications among postmenopausal women in the UK General Practice Research Database. Menopause 2012;19:33-40.

69. Lin TC, Yang CY, Yang YH, et al. Alendronate adherence and its impact on hip-fracture risk in patients with established osteoporosis in Taiwan. Clin Pharmacol Ther 2011;90:109-16.

70. Lo JC, Pressman AR, Omar MA, et al. Persistence with weekly alendronate therapy among postmenopausal women. Osteoporos Int 2006;17:922-8.

71. Martin KE, Yu J, Campbell HE, et al. Analysis of the comparative effectiveness of 3 oral bisphosphonates in a large managed care organization: adherence, fracture rates, and all-cause cost. $J$ Manag Care Pharm 2011:17:596-609.

72. McCombs JS, Thiebaud P, McLaughlin-Miley C, et al. Compliance with drug therapies for the treatment and prevention of osteoporosis. Maturitas 2004:48:271-87.

73. Modi A, Tang J, Sen S, et al. Osteoporotic fracture rate among women with at least 1 year of adherence to osteoporosis treatment Curr Med Res Opin 2015;31:767-77.

74. Modi A, Siris S, Yang X, et al. Association between gastrointestinal events and persistence with osteoporosis therapy: analysis of administrative claims of a U.S. managed care population. J Manag Care Spec Pharm 2015;21:499-506.

75. Modi A, Sajjan S, Michael Lewiecki E, et al. Relationship between gastrointestinal events and compliance with osteoporosis therapy: an administrative claims analysis of the US managed care population. Clin Ther 2016;38:1074-80.

76. Netelenbos JC, Geusens PP, Ypma G, et al. Adherence and profile of non-persistence in patients treated for osteoporosis--a large-scale, long-term retrospective study in The Netherlands. Osteoporos Int 2011;22:1537-46.

77. Olsen KR, Hansen C, Abrahamsen B. Association between refill compliance to oral bisphosphonate treatment, incident fractures, and health care costs--an analysis using national health databases. Osteoporos Int 2013;24:2639-47.

78. Papaioannou A, loannidis G, Adachi JD, et al. Adherence to bisphosphonates and hormone replacement therapy in a tertiary 
care setting of patients in the CANDOO database. Osteoporos Int 2003:14:808-13.

79. Patrick AR, Brookhart MA, Losina E, et al. The complex relation between bisphosphonate adherence and fracture reduction. $J$ Clin Endocrinol Metab 2010;95:3251-9.

80. Penning-van Beest FJ, Goettsch WG, Erkens JA, et al. Determinants of persistence with bisphosphonates: a study in women with postmenopausal osteoporosis. Clin Ther 2006;28:236-42.

81. Penning-van Beest FJ, Erkens JA, Olson M, et al. Loss of treatment benefit due to low compliance with bisphosphonate therapy. Osteoporos Int 2008;19:511-7.

82. Penning-van Beest FJ, Erkens JA, Olson M, et al. Determinants of non-compliance with bisphosphonates in women with postmenopausal osteoporosis. Curr Med Res Opin 2008;24:1337-44

83. Rabenda V, Mertens R, Fabri V, et al. Adherence to bisphosphonates therapy and hip fracture risk in osteoporotic women. Osteoporos Int 2008;19:811-8.

84. Recker RR, Gallagher R, MacCosbe PE. Effect of dosing frequency on bisphosphonate medication adherence in a large longitudinal cohort of women. Mayo Clin Proc 2005;80:856-61.

85. Reynolds K, Muntner P, Cheetham TC, et al. Primary non-adherence to bisphosphonates in an integrated healthcare setting. Osteoporos Int 2013;24:2509-17.

86. Richards JS, Cannon GW, Hayden CL, et al. Adherence with bisphosphonate therapy in US veterans with rheumatoid arthritis. Arthritis Care Res 2012;64:1864-70.

87. Rietbrock S, Olson M, van Staa TP. The potential effects on fracture outcomes of improvements in persistence and compliance with bisphosphonates. QJM 2009;102:35-42.

88. Roerholt C, Eiken P, Abrahamsen B. Initiation of anti-osteoporotic therapy in patients with recent fractures: a nationwide analysis of prescription rates and persistence. Osteoporos Int 2009;20:299-307.

89. Roughead EE, Ramsay E, Priess K, et al. Medication adherence, first episode duration, overall duration and time without therapy: the example of bisphosphonates. Pharmacoepidemiol Drug Saf 2009;18:69-75.

90. Sampalis JS, Adachi JD, Rampakakis E, et al. Long-term impact of adherence to oral bisphosphonates on osteoporotic fracture incidence. J Bone Miner Res 2012;27:202-10.

91. Scotti L, Arfè A, Zambon A, et al. Cost-effectiveness of enhancing adherence with oral bisphosphonates treatment in osteoporotic women: an empirical approach based on healthcare utilisation databases. BMJ Open 2014;4:e003758.

92. Sheehy O, Kindundu CM, Barbeau M, et al. Differences in persistence among different weekly oral bisphosphonate medications. Osteoporos Int 2009;20:1369-76.

93. Siris ES, Harris ST, Rosen CJ, et al. Adherence to bisphosphonate therapy and fracture rates in osteoporotic women: relationship to vertebral and nonvertebral fractures from 2 US claims databases. Mayo Clin Proc 2006;81:1013-22.

94. Siris ES, Pasquale MK, Wang Y, et al. Estimating bisphosphonate use and fracture reduction among US women aged 45 years and older, 2001-2008. Journal of Bone and Mineral Research $2011 ; 26: 3-11$.
95. Soong YK, Tsai KS, Huang HY, et al. Risk of refracture associated with compliance and persistence with bisphosphonate therapy in Taiwan. Osteoporos Int 2013;24:511-21.

96. Ström $\mathrm{O}$, Landfeldt $\mathrm{E}$. The association between automatic generic substitution and treatment persistence with oral bisphosphonates. Osteoporos Int 2012;23:2201-9.

97. Sunyecz JA, Mucha L, Baser O, et al. Impact of compliance and persistence with bisphosphonate therapy on health care costs and utilization. Osteoporos Int 2008;19:1421-9.

98. Tafaro L, Nati G, Leoni E, et al. Adherence to anti-osteoporotic therapies: role and determinants of "spot therapy". Osteoporos Int 2013;24:2319-23

99. van Boven JF, de Boer PT, Postma MJ, et al. Persistence with osteoporosis medication among newly-treated osteoporotic patients. J Bone Miner Metab 2013;31:562-70.

100. van den Boogaard CH, Breekveldt-Postma NS, Borggreve SE, et al. Persistent bisphosphonate use and the risk of osteoporotic fractures in clinical practice: a database analysis study. Curr Med Res Opin 2006;22:1757-64.

101. Wang Z, Ward MM, Chan L, et al. Adherence to oral bisphosphonates and the risk of subtrochanteric and femoral shaft fractures among female medicare beneficiaries. Osteoporos Int 2014:25:2109-16.

102. Weiss TW, Henderson SC, McHorney CA, et al. Persistence across weekly and monthly bisphosphonates: analysis of US retail pharmacy prescription refills. Curr Med Res Opin 2007;23:2193-203.

103. Weycker D, Macarios D, Edelsberg J, et al. Compliance with drug therapy for postmenopausal osteoporosis. Osteoporos Int 2006;17:1645-52.

104. Weycker D, Lamerato L, Schooley S, et al. Adherence with bisphosphonate therapy and change in bone mineral density among women with osteoporosis or osteopenia in clinical practice. Osteoporos Int 2013:24:1483-9.

105. Yeaw J, Benner JS, Walt JG, et al. Comparing adherence and persistence across 6 chronic medication classes. J Manag Care Pharm 2009:15:728-40.

106. Yood RA, Emani S, Reed JI, et al. Compliance with pharmacologic therapy for osteoporosis. Osteoporos Int 2003;14:965-8.

107. Zambon A, Baio G, Mazzaglia G, et al. Discontinuity and failures of therapy with bisphosphonates: joint assessment of predictors with multi-state models. Pharmacoepidemiol Drug Saf 2008;17:260-9.

108. Ziller V, Kostev K, Kyvernitakis I, et al. Persistence and compliance of medications used in the treatment of osteoporosis--analysis using a large scale, representative, longitudinal German database. Int J Clin Pharmacol Ther 2012;50:315-22.

109. Hess LM, Raebel MA, Conner DA, et al. Measurement of adherence in pharmacy administrative databases: a proposal for standard definitions and preferred measures. Ann Pharmacother 2006;40:1280-8.

110. Sikka R, Xia F, Aubert RE. Estimating medication persistency using administrative claims data. Am J Manag Care 2005; $11: 449-57$

111. Steiner JF, Prochazka AV. The assessment of refill compliance using pharmacy records: methods, validity, and applications. J Clin Epidemiol 1997;50:105-16. 